高分子化学 (Kobunshi Kagaku), Vol. 28, No. 312, pp. 361-367 (Apr., 1971)

increase in maleimide content. However, the product $T_{0} \Delta \alpha$, where $\Delta \alpha$ is the difference in volume expansion above and below glass transition temperature, is nearly constant, regardless of copolymer compositions.

KEY WORDS Glass Transition Temperature / Dilatometer / Gopolymer / Maleimide / $N$-Phenyl Maleimide / Methyl Acrylate / Methyl Methacrylate / Volume Expansion /

\author{
エチレン共重合により変性したポリビニル \\ アルコール水溶液の性質
}

（1970年10月30日受理）

柴谷享一郎* ・大柳康治*

\begin{abstract}
要 旨 酢酸ビニルとエチレンのランダム共重合物（エチレン基含量約 $10 \mathrm{~mol} \%$ 以下）をケン化 して得られるエチレン基含有ポリビニルアルコールの水溶液の性啠を研究した。この水溶液はある 閉した温度，䈨度域で 2 相に分晟する。2つの臨界完溶温度，LCST とUCST はエチレン基含量 が小さいほど，また分子量が小さいほどたがいに 70〜90 付近へ接近し，エチレン基含量 $3 \mathrm{~mol} \%$ 以下の試料ではつねに均一溶液となる。分子量無限大のポリマーに外拽した LCST での粘度一分子 量関保の測定および沈降平衡法による第 2 ビリアル係数測定の結果, この温度は $\Theta$ 温度であること が確認された。また, このポリマーの水溶液の極限粘度の温度依存性を調へた。これらの結果より 純ポリビニルアルコール水溶液の溶解状態にっいて考察し, 溶解性は $80^{\circ} \mathrm{C}$ 付近で最も悪いこと, ま た溶解は $80^{\circ} \mathrm{C}$ 以下では発热的, $80^{\circ} \mathrm{C}$ 以上では吸熱的に起こると推定した。
\end{abstract}

\section{1. 緒 言}

ポリビニルアルコール (PVA) の水に対する溶解性以

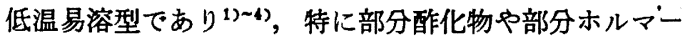
ル化物の水溶液ではそれ以上の温度ではもはや均一な溶 液とならず相分離が起こる温度, lower critical solution temperature (LCST) が存在する5 こでが知られてい る。しかし結晶性の PVA を水に溶解させるためには高 温を用いることが通常の操作であり, シンジオタクチシ ティの高、PVAでは, $160^{\circ} \mathrm{C} て ゙$ 初めて水に溶解すること も報告されており ${ }^{8)}$, PVAの水に対する溶解性の温度依 存性には不明な点も存在している。ポリエチレングリコ ールの水溶液については LCSTょり高温域で再ですべ ての濃度で均一な溶液が得られる温度, upper critical solution temperature (UCST) が存在することが知られ

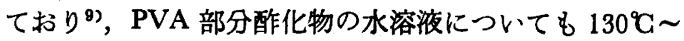

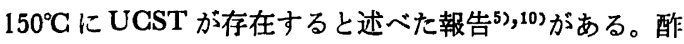
酸ビニルと少量のエチレンのランダム共重合物(PVAcE) をケン化して得られるわずかにェチレン基で変性した

* 株式会社クラレ 中央研究所 (岡山県倉数市酒津青 江山 2045 の 1)
PVA (PVAE). (エチレン基含有量約 $10 \mathrm{~mol} \%$ 以下) の水 溶液について，筆者らは比較的低温に LCST と UCST が存在し，その中間の温度についてはある濃度領域で溶 液は 2 相に分離することを見出した。非極性のポリマー 一溶剂系の溶液について溶剂の沸点以上, 臨界温度近く に LCST が存在し，これが状態方程式により解析できる ことが最近の多数の研究により明らかにされたが11) 14), 以前より知られていた極性ポリマー，極性溶剤系のLCS Tについては上述のもの以外にポリビニルメチルエーテ ルおよびメチルセルロースの水溶液 ${ }^{15), 16), ~ フ ェ ニ ル ウ レ ~}$

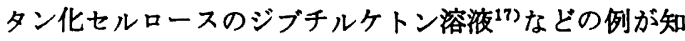
られているが，あまり研究はなされていない。ここでは PVAE 水溶液の上下両臨界温度とポリマーのエチレン基 含有量, 分子量の関保を詳細に測定し, この特異な挙動 を解析すること，さらにこの結果より純 PVA の水溶液 の溶解状態に関する知見を得ることを試みた。

\section{2. 実験}

\section{1 試 料}

酶酸ビニルとエチレンの共重合は次のようにして行な った。容量 $1 l$ のオートクレーブに酢酸ビニル $500 \mathrm{ml}$ と触媒のアゾビスイソブチロニトリルを入れ，次にエチ 
レンを所定の圧力まで封入し $60^{\circ} \mathrm{C} て ゙$ 重合させた。一定時 間反応後チオ尿素を加えて重合を停止し, 重合物を水中 に取り出し，次に熱水中に浸すことにより未反応のモノ マーを追い出した。共重合体中の組成分布を少なくする ため重合率はできるだけ低く抑えた。ケン化に伴ら重合 度の変化が分別陚料について起こらないようにするため 重合物はあらかじ常法に従ってケン化し, 再び常法に より完全酢化して未分別 PVAcE 試料とした。重合条件 および試料の性質を Table 1 に示す。酢酸ビニ゙ル (1) とエチレン(2)の共重合反応性比は $90^{\circ} \mathrm{C}, 1000$ 気圧で $r_{1}$ $=1.08, r_{2}=1.07$ であり ${ }^{18)}$ ，また高分解能 NMR 測定に よると酢酸ビニル含量の多い溶液共重合体についてのエ チレン基の分布はまったくランダムである ${ }^{19)}$ と報告され ている。したがって，ここに用いる共重合体試料でのエ チレン基の分布はすべてランダムであると考えられる。

再酢化試料は上田の方法 ${ }^{20)}$ にならいメチルエチルケト ンーシクロヘキサン系でカラム分別した。溶出液中のメ チルエチルケトンの体積分率 $\gamma$ は 0.30 より 0.60 まで変
え，最後にアセトンを用いることにより17区分に分別し た。重量に関する回収率はすべて $99 \%$ 以上であり，各区 分の重量分率 $w$ 、と極限粘度 $[\eta]$ 、より $\Sigma w_{\text {، }}[\eta]$ を計算し たところ PVAcE-1〜4 についてそれぞれ 1.100, 1.015， $0.914,0.863(\mathrm{~d} l / \mathrm{g})$ であった。比較的量の多、第 3 区分 より第11区分までについて，エチレン基含有量と数平均 分子量 $\bar{M}_{n}$ を測定した。エチレン基含有量の測定は多少 熟練を要したが次のようにして行なった。試料 $0.1 \mathrm{~g}$ を 精製メタノール $20 \mathrm{~m} l$ に溶解し, $N / 10$ カセイソーダ水 溶液 $20 \mathrm{ml}$ を逐次加え, 密栓して50畐に 4 時間保ちケン 化が完了した後冷却し， $N / 10$ 硫酸 $30 \mathrm{ml}$ を加え $N / 10$ カセイソーダで这滴定して試料中の酢酸基量を計算し た。 $\bar{M}_{n}$ はトルエンを溶媒として Dohrman 社製メンブ ランオスモメーターを用い測定した。膜にはウルトラセ ラフィルター allerfeinst (Sartorius) を用い, 測定温度は $35^{\circ} \mathrm{C}$ とした。これらの結果を Table 2 に示す。各区分の エチレン含有量はほとんど一定であり，エチレン含有量 が $10 \mathrm{~mol} \%$ 程度以下ではメチルエチルケトンーシクロ

Table 1. Preparation conditions and characterization of samples.

\begin{tabular}{|c|c|c|c|c|c|c|}
\hline \multirow{3}{*}{ Sample } & \multicolumn{4}{|c|}{ Polymerization conditions ${ }^{\mathrm{a}}$ ) } & \multicolumn{2}{|c|}{ Properties } \\
\hline & \multirow{2}{*}{$\begin{array}{l}\mathrm{C}_{2} \mathrm{H}_{4} \\
(\mathrm{~atm})\end{array}$} & \multirow{2}{*}{$\underset{(\mathrm{g})}{\operatorname{AIBN}}$} & \multicolumn{2}{|c|}{ Polymerization } & \multirow{2}{*}{$\begin{array}{c}\mathrm{C}_{2} \mathrm{H}_{4} \\
\text { content } \\
\text { (mol\%) }\end{array}$} & \multirow{2}{*}{$\begin{array}{c}{[\eta] 30^{\circ} \mathbf{C}} \\
\text { acetone } \\
(\mathrm{d} l / \mathrm{g})\end{array}$} \\
\hline & & & Time $(\mathrm{hr})$ & conv. $(\%)^{b)}$ & & \\
\hline PVAcE-1 & 5.9 & 0.09 & 3.0 & 27 & 5.4 & 1.103 \\
\hline 2 & 9.2 & 0.10 & 3.5 & 21 & 8.7 & 1.024 \\
\hline 3 & 12.4 & .0 .10 & 4.0 & 23 & 10.9 & 0.897 \\
\hline 4 & 14.8 & 0.11 & 4.3 & 25 & 12.6 & 0.850 \\
\hline
\end{tabular}

a) $500 \mathrm{ml}$ of vinyl acetate was polymerized at $60^{\circ} \mathrm{C}$.

b) Calculated about vinyl acetate, from the weight of obtained copolymer and the vinyl acetate content in the copolymer.

Table 2. Results of fractionation of whole polymers.

\begin{tabular}{|c|c|c|c|c|c|c|c|c|}
\hline \multirow{2}{*}{$\begin{array}{c}\text { Fraction } \\
\text { No. }\end{array}$} & \multicolumn{2}{|c|}{ PVAcE-1a) } & \multicolumn{2}{|c|}{ PVAcE-2b) } & \multicolumn{2}{|c|}{ PVAcE-3c) } & \multicolumn{2}{|c|}{ PVAcE-4d } \\
\hline & $\bar{M}_{n} \times 10^{-4}$ & $\begin{array}{c}-\mathrm{C}_{2} \mathrm{H}_{4}- \\
(\mathrm{mol} \%)\end{array}$ & $\bar{M}_{n} \times 10^{-4}$ & $\begin{array}{c}-\mathrm{C}_{2} \mathrm{H}_{4}- \\
(\mathrm{mol} \%)\end{array}$ & $\bar{M}_{n} \times 10^{-4}$ & $\begin{array}{c}-\mathrm{C}_{2} \mathrm{H}_{4}- \\
(\mathrm{mol} \%)\end{array}$ & $\bar{M}_{n} \times 10^{-4}$ & $\begin{array}{c}-\mathrm{C}_{\mathrm{q}} \mathrm{H}_{4} \\
(\mathrm{~mol} \%)\end{array}$ \\
\hline 3 & 2.39 & 5.7 & 2.67 & 9.0 & 2.62 & 11.8 & 2.22 & 12.9 \\
\hline 4 & 3.90 & 6.2 & 5.07 & 9.0 & 4.46 & 11.1 & 3.69 & 12.8 \\
\hline 5 & 6.50 & 5.7 & 8.27 & 9.1 & 8.74 & 10.4 & 5.56 & 13.3 \\
\hline 6 & 10.05 & 6.3 & 11.46 & 9.1 & 11.02 & 11.0 & 7.80 & 12.8 \\
\hline 7 & 13.06 & 6.2 & 14.4 & 9.0 & 12.1 & 11.2 & 10.79 & 12.8 \\
\hline 8 & 18.4 & 5.9 & 20.9 & 8.9 & 16.3 & 11.1 & 13.8 & 12.9 \\
\hline 9 & 25.4 & 5.9 & 30.0 & 9.1 & 18.7 & $(10.0)$ & 18.9 & 12.9 \\
\hline 10 & 41.5 & 5.6 & 41.5 & 8.7 & 26.9 & 11.1 & 28.4 & 12.7 \\
\hline 11 & 84.3 & 5.6 & 84.3 & 8.1 & 40.2 & 11.0 & 47.5 & 12.1 \\
\hline Average & & 5.9 & & 9.0 & & 11.1 & & 12.8 \\
\hline
\end{tabular}

$\bar{M}_{n}$ of PVAE samples are estimated by multiplying $\bar{M}_{n}$ of PVAcE samples by following factors, 0.5215 for a), 0.5269 for $b), 0.5307$ for c) and 0.5339 for d), respectively. 


\section{エチレン共重合により変性したポリビニルアルコール水溶液の性啠}

ヘキサン系の分別条件で分別は分子量によってのみ行な われているといえる。これは未分別 PVAcE 試料中での 組成分布の幅が小さいためと考えられる。また GPG に より推定した数平均と重量平均の分子量の比は 1.2 から 1.3 の間であり分別区分間での差はほとんどなかった。

Table 2 の各区分をケン化し分別 PVAE 試料を得た。 ケン化により重合度は変わらないとして PVAE 試料の $\bar{M}_{n}$ を計算により求めた。なお，ケン化物の精製は，低 分子量区分については損失が次いように透析，凍結乾燥 を行なった。

\subsection{PVAE 水溶液の臨界完溶温度の測定}

試料を水とともにガラス管に封入し，そのガラス管を シリコーン浴に浸せきして均一な溶液が白濁する温度を 測定した。白濁の開始は目測により知った。すなわちU CST については十分昇温した溶液の温度を低下させる ことにより観測し，LCSTについては一度昇温して均一 溶液としたものを急冷し，その後ゅっくり䄯温すること により観測した。シリコーン浴の温度は制御部として接 触温度計を用い，頭部を减速モーターに連結して $0.5^{\circ} \mathrm{C}$ /min の速さで昇温, 降温した。白阔が起こる温度の近 傍では温度変化は $0.1^{\circ} \mathrm{C} / \mathrm{min}$ とした。

\section{3 粘度測定}

オストワルド型粘度計を用い水溶液濃度 4 点について 粘度を測定し, 極限粘度 $[\eta]$ を求めた。溶液の浱度は相

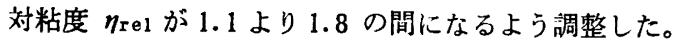
粘度測定用恒温槽は臨界完溶温度測定の場合と同じ基淮 温度計で較正した温度計を用い，設定温度 $\pm 0.01^{\circ} \mathrm{C}$ に保 った。

\section{4 沈降平衡実験}

沈殿点法により求めた $\theta$ 温度を確認するため, Beck-

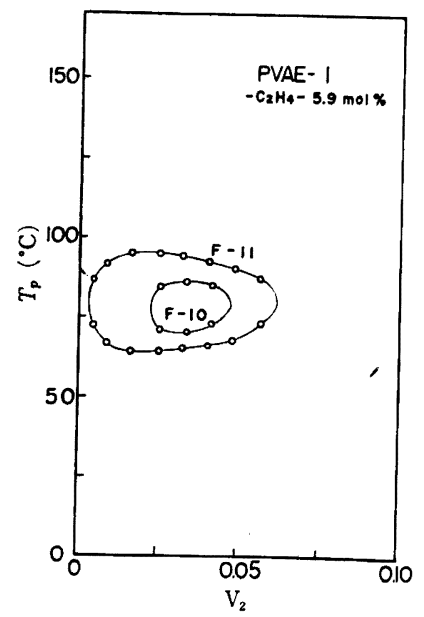

Fig. 1. Phase diagram for PVAE-1 fractions in water.
man-Spinco E 型超遠心機を用い，沈降平衡法により第 2 ビリアル係数を求めた。測定は An-G 型ローターを用 い, ローター回転数 $10000 \mathrm{rpm}$, 液柱の高さ $1.5 \mathrm{~mm}$ で Rayleigh 干涉光学系により行なった。

\section{3. 結 果}

分別 PVAE 水溶液の相図を Fig. 1 4 に示す。エチ レン基含有量が $5.9 \mathrm{~mol} \%$ である PVAE-1ににいては, 低分子量区分ではすべての簌度 $\left(v_{2}\right.$ は水溶液中でのポリ マーの体積分率）で均一な溶液が得られたが，高分子量 区分である PVAE-1-10, 11 については 65 95 9 C の範囲 で相分離が起こり均一な溶液が得られない濃度域が存在

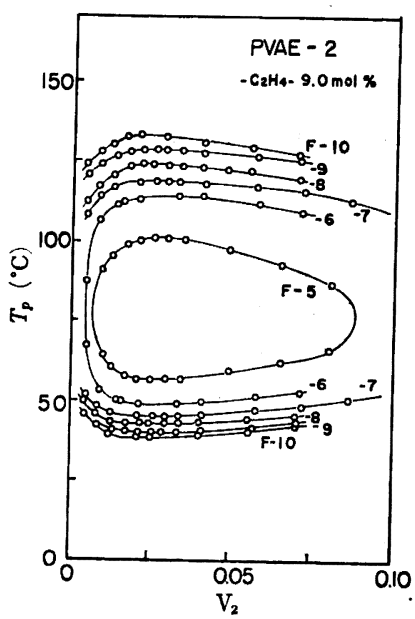

Fig. 2. Phase diagram for PVAE-2 fractions in water.

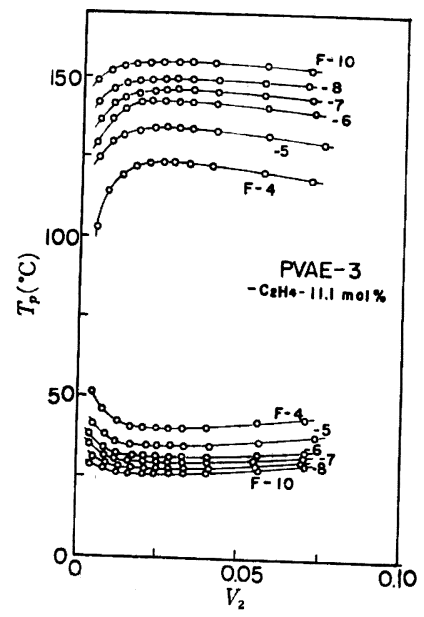

Fig. 3. Phase diagram for PVAE-3 fractions in water. 


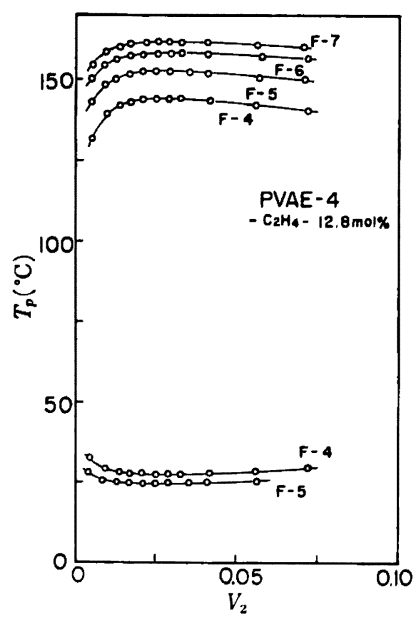

Fig. 4. Phase diagram for PVAE-4 fractions in water.

する。このような相分離が起こる温度, 濃度域はエチレ ン基含量が大きいほど，また試料の分子量が大きいほど 大きくなることが Fig. 1〜4の比較により明らかになる。 エチレン基含量が $12.8 \mathrm{~mol} \%$ である PVAE-4 の高分子 量区分では LCST は $25^{\circ} \mathrm{C}$ 以下，UCST は $160^{\circ} \mathrm{C}$ 以上とな り測定が容易でなくなったので実験を行なわなかった。

分子量無限大のポリマーの臨界完溶温度 $T_{c}$ は排除体 積効果が見かけ上 0 となる $\Theta$ 温度と考えられる ${ }^{21)}$ 。分子 量と $T_{\mathrm{c}}$ の関係より $\theta$ 温度を定めるために Fig. 5 に Flory

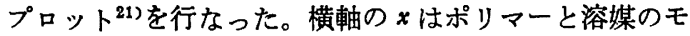
ル体積の比であり, $x=\bar{M}_{n} / 1.27 \times 18$ として計算した。 低分子量試料ではわずかに直線からのずれも認められる が，LCST および UCST ともきれいに $\bar{M}_{n} \rightarrow \infty$ に外挿 できる。このようにして求めた各試料の水溶液に対する $\theta_{\text {LCST, }} \theta_{\text {UCST }}$ を Table 3 に示す。エチレン基含有量が $5.9 \mathrm{~mol} \%$ である PVAE-1 については $\theta_{\mathrm{LCST}}$ と $\theta_{\mathrm{UCST}}$

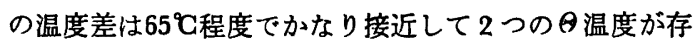
在することになる。LGST の $\bar{M}_{n} \rightarrow \infty$ への外捙が正しく 行なわれているかどうかを確認するため, PVAE-2 の1 つの分別区分についてだけ $\theta_{\mathrm{LCST}}=29.8^{\circ} \mathrm{C}$ で超遠心機 を用い沈降平衡法により第 2 ビリアル倸数 $A_{2}$ を求めた

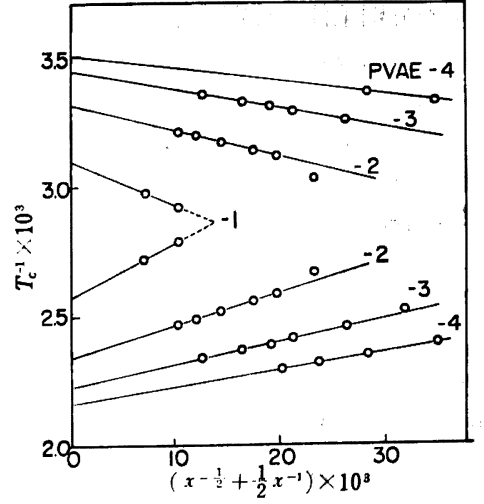

Fig. 5. Plots between reciprocal critical temperature and degree of polymerization according to Schultz and Flory ${ }^{85)}$ for PVAE fractions in water.

ところ, $A_{2}=0$ であり, $\Theta_{\mathrm{LCST}}$ で非摂動状態にあること が確かめられた。

PVAE-2 および PVAE-3 の試料についてそれぞれ $\theta_{\text {LCST }}$ である $29.8^{\circ} \mathrm{C}, 17.6^{\circ} \mathrm{C}$ で測定した $[\eta]$ と分子量 $\bar{M}_{n}$ の関係を Fig. 6 に示した。この図より粘度式は次の ように定められた。

$$
\begin{aligned}
& \text { PVAE-2, } 29.8^{\circ} \mathrm{C} ; \quad[\eta]=1.59 \times 10^{-2} \bar{P}_{n}^{0.5} \\
& \text { PVAE }-3,17.6^{\circ} \mathrm{G} ; \quad[\eta]=1.68 \times 10^{-2} \bar{P}_{n}^{0.5}
\end{aligned}
$$

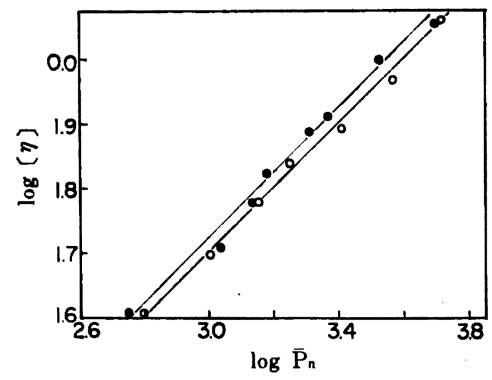

Fig. 6. Double logarithmic plots of $[\eta]_{\theta}$ against number average degree of polymerization $\bar{P}_{n}$ for PVAE fractions: (O) PVAE-2 in water at $29.8^{\circ} \mathrm{C}$; (O) $\mathrm{PVAE}-3$ in water at $17.6^{\circ} \mathrm{C}$.

\begin{tabular}{|c|c|c|c|c|c|c|c|}
\hline \multirow{2}{*}{ Sample } & \multirow{2}{*}{$\begin{array}{c}-\mathrm{C}_{22} \mathrm{H}_{4}- \\
\text { content } \\
(\mathrm{mol} \%)\end{array}$} & \multicolumn{2}{|c|}{$\theta\left({ }^{\circ} \mathrm{C}\right)$} & \multicolumn{2}{|c|}{$\varphi_{1}$} & \multicolumn{2}{|c|}{$\kappa_{1}$} \\
\hline & & UGST & LGST & UCST & LGST & $\begin{array}{l}\text { UCST } \\
400^{\circ} \mathrm{K}\end{array}$ & $\begin{array}{l}\text { LCST } \\
300^{\circ} \mathrm{K}\end{array}$ \\
\hline PVAE-1 & 5.9 & $116.1=$ & 51.3 & 0.12 & -0.19 & 0.12 & -0.21 \\
\hline 2 & 9.0 & 155.3 & 29.8 & 0.19 & -0.33 & 0.20 & -0.33 \\
\hline 3 & 11.1 & 176.0 & 17.6 & 0.25 & -0.47 & 0.28 & -0.45 \\
\hline 4 & 12.8 & 190.4 & 12.5 & 0.31 & -0.67 & 0.36 & -0.65 \\
\hline
\end{tabular}

Table 3. Results of determination of thermodynamic parameters for systems PVAE and water. 


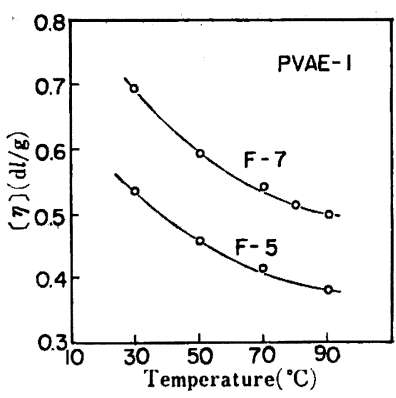

Fig. 7. Plots of $[\eta]$ vs. temperature for fraction 5 and 7 of PVAE-1.

粘度式における重合度の指数は 0.5 であり， $\theta_{\mathrm{LCST}}$ では 遠距離相互作用は消え，分子鎖はガウス統計に従うこと が確認された。ただし PVAE-1では，

PVAE $-1,50.6^{\circ} \mathrm{G} ;[\eta]=2.52 \times 10^{-2} P_{n}{ }^{0.48}$

となり，50.6要の水は $\theta$ よりさらに貧溶媒となってい る。これは $\theta$ 決定のための $T_{\mathrm{e}}$ の測定数が少なすぎ，外 拍が不正確であったためではないかと考えられる。

最後に，PVAE-1-5 および PVAE-1-7 について $[\eta]$ と温度の関係を測定した結果を Fig. 7 に示す。 [ $\eta$ は は温 度の上昇とともに小さくなり， $d[\eta] / d T$ の絶対値は高温 になるに従い明りょうに減少している。

\section{4. 端論}

非極性ポリマー，非極性溶媒の系について認められる LCST は球対称ポテンシャル (Lennard-Jones) を仮定し た corresponding state 則22)を用いた状態方程式により解 析され，LCST の起こる原因は低分子物質である溶媒の 臨界温度付近で溶媒のモル容積が著しく增大し，混合に

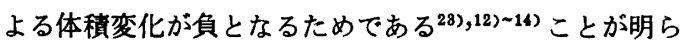
かにされた。極性ポリマー，極性溶媒の系についてはこ のような corresponding state 則は適用しにくく，また本 報告で用いた溶媒, すなわち, 水の臨界温度は $374^{\circ} \mathrm{C}^{24)}$ であり，実験で用いた温度はこれよりはるかに低い。し たがって，PVAE-水系の LCST, UCST はともに水素結

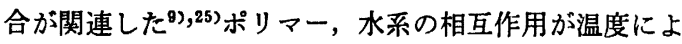
り変化するために起こると考えられる。Fig. 8 はエチレ ン基含有量と $\theta_{\mathrm{LCST}}, \theta_{\mathrm{UCST}}$ の関係を図示したものであ るが，上下 2 つの曲線で囲まれた範囲内では相分離が観 測される鈸度域が存在するわけである。この事実は次の ように理解される。すなわち，PVAE 水溶液を昇温する とまずポリマー, 水分子間の水素結合が切断され始め溶 解性が低下し，遂に溶液は 2 相に分離する。しかし，さ らに昇温すると水分子自体の水素結合構造の変化, ポリ マーの分子内水素結合の開裂が起こり再び溶解性が増し 均一な溶液が得られるようになるのであろう。また，疎

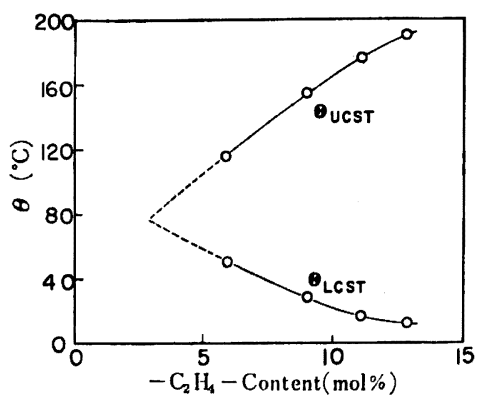

Fig. 8. $\theta$ temperatures as a function of ethylene content of PVAE samples.

水性のエチレン基が導入されるとともに水に対する溶解 性が低下するので，ポリマー中のエチレン基含有量が 5 $\mathrm{mol} \%$ より増加するに伴い相分離が起こる温度範囲が広 がるのであろう。

$\Theta_{\mathrm{LCST}}$ と $\theta_{\mathrm{UCST}}$ の両曲線を低エチレン基含有量側に 外捜すると，エチレン基 $3 \mathrm{~mol} \%$ 程度のところで両曲線 は交わる。したがって, エチレン含有量が $3 \mathrm{~mol} \%$ 以下 の PVAE は分子量によらず，すべての温度，漶度域で 水と完全に相溶するといえるだろう。また純 PVA 水溶 液の場合, $70^{\circ} \mathrm{C}$ 程度までは昇温とともに溶解性が低下 し， $70 \sim 90^{\circ} \mathrm{C}$ 間で溶解性が最も悪くなるが，相分離を起 こすことはなく，さらに昇温すると逆に溶解性は良好に なると推定される。このことは PVA-水系の溶解性パラ

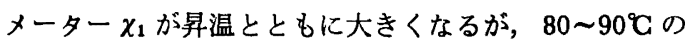
間で温度変化がほとんどなくなることを示した桜田らの 報告 ${ }^{26)}$ の結果ともよく一致する。また松尾らはPVA 水 溶液の光散乱, 粘度測定を行ない, 第 2 ビリアル係数 $A_{2}$ および $[\eta]$ は温度の上昇とともに低下すること, $80^{\circ} \mathrm{Cで}$ は $A_{2} \bar{M}_{w} /[\eta]=31$ (良溶媒系では 70 150), $[\eta]=9.4$ $\times 10^{-4} \bar{M}_{w}{ }^{0.56}$ となり，水の PVA に対する溶解性はよく

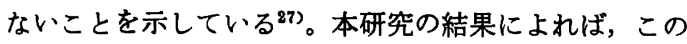
$80^{\circ} \mathrm{C}$ における測定が $200^{\circ} \mathrm{C}$ 程度以下において水が PVA に対しほぼ最も貣溶媒である場合の测定に相当すると推 定される。

スチレンーメタクリル酸メチル共重合体に関する広範 な研究によれは28) -80), 希薄溶液に関する二定数理 論は 共重合体に関しても拡張でき，さらにモノマー単位とし て適当なものを採用すればホモポリマー（交互共重合体 などを含む）に関するパラメーターにより共重合体溶液 の性質はかなりよく記述できる。PVAEを構成するエチ レン基とビニルアルコール基はかなり異なった性格を有 しており，溶媒である水との相互作用は著しく異なると 考えられるが，ここではPVAE 水溶液に対しても通常 の希薄溶液理論が適用できると仮定してさらに検尉を進 める。Flory-Fox によれば極哣粘度 $[\eta]$ は非揟動鎖の末 
端間距離の自乗平均 $\left\langle R_{0}{ }^{2}\right\rangle$, 商分子鎖の広がりの因子 $\alpha$ により次のように書ける ${ }^{81}$ 。

$$
[\eta]=\Phi\left(\frac{\left\langle R_{0}{ }^{2}\right\rangle}{M}\right)^{8 / 2} M^{1 / 2} \alpha^{3}
$$

ここで で微分すると次式を得る。

$$
\frac{d \ln [\eta]}{d T}=\frac{3}{2} \frac{d \ln \left\langle R_{0}{ }^{2}\right\rangle}{d T}+\frac{d \ln \alpha^{3}}{d T}
$$

Stockmayerら ${ }^{28}$ は共重合体の $\left\langle R_{0}{ }^{2}\right\rangle$ について次式が近似 的に成立すると述べている。

$$
\frac{\left\langle R_{0}^{2}\right\rangle}{M}=w_{\Delta}\left(\frac{\left\langle R_{0}^{2}\right\rangle}{M}\right)_{A}+w_{B}\left(\frac{\left\langle R_{0}^{2}\right\rangle}{M}\right)_{B}
$$

ここで $w_{A}, w_{B}$ は共重合体成分 $\mathrm{A}, \mathrm{B}$ の重量分率である。 PVA では 50亿で $d \ln \left\langle R_{0}{ }^{2}\right\rangle / d T=-1.7 \times 10^{-8}\left(d \ln \left\langle R_{0}^{2}\right\rangle\right.$ $/ d T=-0.56 / T)$ であり ${ }^{26)}$, また $\left\langle R_{0}{ }^{2}\right\rangle / M=0.95 \times 10^{-16}$ $\left(\mathrm{cm}^{2} \mathrm{~mol} \mathrm{deg}^{-1}\right)$ である $\left.{ }^{22}\right)$ 。ポリエチレンでは,

$$
\begin{aligned}
& d \ln \left\langle R_{0}{ }^{2}\right\rangle / d T=-0.48 / T^{33)}, \\
& \left.\left\langle R_{0}{ }^{2}\right\rangle / M=1.14 \times 10^{-1684}\right)
\end{aligned}
$$

と報告されている。これらの数値を用い(6) 式よりエチ レン基含有量 $5.9 \mathrm{~mol} \%$ の PVAE-1 について $d \ln \left\langle R_{0}{ }^{2}\right\rangle$ $/ d T$ を計算すると $-1.69 \times 10^{-8}$ となる。PVAE-2, -3 についての $\boldsymbol{\theta}$ 温度での粘度式 (1)，(2) よりエチレン基含 有量 $9.0 \mathrm{~mol} \%$ と $11.1 \mathrm{~mol} \%$ の差による $\left\langle R_{0}{ }^{2}\right\rangle$ の変化 を無視して $d \ln \left\langle R_{0}{ }^{2}\right\rangle / d T$ を(5) 式より直接計算すると

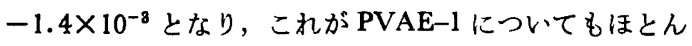
どそのまま適用できるとすると（6) 式より計算した值と かなり近い值になっているわけである。これらの取扱い はPVA とポリエチレンの $\Theta$ 状態での広がりとその温度 依存性がかなり近い值となることから一応許されるであ ろう。ここでは $d \ln \left\langle R_{0}{ }^{2}\right\rangle \mid d T=-1.4 \times 10^{-8}$ を採用し,

Fig. 7 を図上微分して $d \ln [\eta] / d T$ を求め, $\alpha$ の温度変化 を計算したものを Fig. 9 に示した。 $d \ln \alpha^{8} / d T$ は $85^{\circ} \mathrm{C}$ 付 近で負より正になる。すなわち, 極限粘度の温度変化か らも PVAE-1 の溶解性は 85 C 付近で最も悪くなること が認められる。

最後に, PVAの溶液状態での化学反応により作成さ

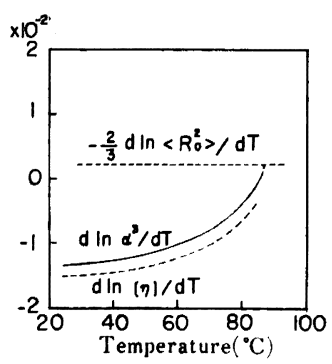

Fig. 9. Relation between $d \ln \alpha^{8} / d T$ and temperature for PVAE-1 in water.
れた部分置換体と PVAE との水に対する溶解状態の比 校を行なってみる。Flory-Huggins の取扱いによれば, 臨界完溶温度 $T_{\mathrm{c}}$ と $\Theta$ 温度の関係は,

$$
\frac{1}{T_{c}}=\left(\frac{1}{\Theta}\right)\left\{1+\frac{1}{\varphi_{1}}\left(\frac{1}{x^{\frac{3}{3}}}+\frac{1}{2 x}\right)\right\}
$$

で与えられ ${ }^{85)}, \varphi_{1}$ は希瀵エントロピー $\Delta \bar{S}_{1}$ と次の関係に ある。

$$
\Delta \bar{S}_{1}=R \varphi_{1} v_{2}^{2}
$$

また，希釈熱 $\Delta \bar{H}_{1}$ は

$$
\Delta \bar{H}_{1}=R T \kappa_{1} v_{2}^{2}
$$

と書かれ, エンタルピーパラメーター $\kappa_{1}$ が定義されて いる。 $\kappa_{1}$ はまた $\varphi_{1}, \theta$ と次の関係にある。

$$
\kappa_{1}=\Theta \varphi_{1} / T
$$

Fig. 5 の勾配より $\varphi_{1}$ が計算でき，さらに(10)式より $\kappa_{1}$ も求められる。PVAE-水系では温度の変化とともに溶 解性は著しく変化するので, 得られる $\varphi_{1}$ は意味を持つ としても測定温度近傍においてだけであろう。このよう にして求めた $\varphi_{1}, \kappa_{1}$ の值を Table 3 にあわせて示した。 PVA の部分酢化物, 部分ホルマール化物の水溶液につ いても置換度が增すにつれ LCST の $\Theta$ は低下し， $\varphi_{1}$ の 絶対值が大きくなることが報告されている( の実験より求めた $\varphi_{1}$ 值は浸透圧の第 2 ビリアル俰数の 温度依存性から求められる $\varphi_{1}$ 值より一般に大きいこと が知られている21)。そこでここでは相平衡実験より求め た $\kappa_{1}, \varphi_{1}$ についてだけ比較を行なうが, 同一㯰換度で $\varphi_{1}$ を比較するとPVAE の $\varphi_{1}$ は部分酢化物, 部分ホルマー ル化物のそれよりもその絶対值がかなり大きい。これは PVAE-水系において溶媒分子の配向効果が大きいこと を意味していると考えられ, エチレン基の場合他の置換 基の場合よりも踈水性が大きく，ポリマー鎖の分子内水 素結合の切断もいっそう完全に行なわれるためではない かと思われる。

付 記 超遠心機による測定をしていただいた影山喬士 氏および実鈳に協力していただいた日岡実氏に感謝いた します。また, 本論文の発表を許可された会社当局に感 謝いたします。

\section{文献}

1) K. Amaya, R. Fujishiro: Bull. Chem. Soc. Japan, 29, 361 (1956)

2）石川欣造, 河合徹, 徳永嘉夫 : 工化, 55, 736 (1952)

3) H. A. Dieu: J. Polymer Sci., 12, 417 (1954)

4) 桜田一郎, 中島章夫, 滰田 博: 高化, 12, 15 (1955)

5) F. F. Nord, M. Bier, S. N. Timasheff: J. Am. Chem. Soc., 73, 289 (1951)

6) 桜田一郎, 坂口康義, 伊藤順夫 : 高化, 14, 
41 (1957)

7）坂口康義, 伊藤順夫 : 高化, 15, 635 (1958)

8) S. Murahashi, S. Nozakura, M. Sumi, K. Matsumura: J. Polymer, Sci. Part B, 4, 59 (1966)

9) G. N. Malcolm, J. S. Rowlinson: Trans. Faraday Soc., 53, 921 (1957)

10) G. Rehage: Kunststoffe, 53, 605 (1963)

11) P. I. Freeman, J. S. Rowlinson: Polymer, 1, 20 (1959)

12) G. Delmas, D. Patterson, T. Somcynsky: J. Polymer Sci., 57, 79 (1962)

13) P. J. Flory, R. A. Orwoll, A. Vrij: J. Am. Chem. Soc., 86, 3515 (1964)

14) J. M. Bardin, D. Patterson: Polymer, 10, 247 (1969)

15) C. E. Schildknecht: "Vinyl and Related Polymers", 603, Wiley, New York (1952)

16) K. Uda, G. Meyerhoff: Makromol. Chem., 47, 168 (1961)

17) W. Burchard: Polymer, 10, 467 (1969)

18) R. D. Burkhart, N. L. Zutty : J. Polymer Sci. Part A, 1, 1137 (1963)

19) J. Schaefer: J. Phys. Chem., 70, 1975 (1966)

20) 上田実 : 第19回高分子討論会（1970）

21) P. J. Flory: "Principles of Polymer Chemistry", Cornell Univ. Press, New York (1953)

22) I. Prigogine: "The Molecular Theory of Solu- tions", Interscience Publishers, Inc., New York (1957)

23) A. Klinkenberg: Disc. Faraday Soc., 15, 276 (1953)

24) 日本化学会編 : “化学便覧”，536, 丸善 (1960)

25) O. K. Rice: Disc. Faraday Soc., 15, 276 (1953)

26) I. Sakurada, A. Nakajima, K. Shibatani: Makromol. Chem., 87, 103 (1965)

27) M. Matsuo, H. Inagaki: Makromol. Chem., 55, 150 (1962)

28) W. H. Stockmayer, L. D. Moore, Jr., M. Fixman, B. N. Epstein: J. Polymer Sci., 16, 517 (1955)

29) T. Kotaka, Y. Murakami, H. Inagaki: $J$. Phys. Chem., 72, 829 (1968)

30) T. Kotaka, T. Tanaka, H. Ohnuma, Y. Murakami, H. Inagaki: Polymer J., 1, 245 (1970)

31) P. J. Flory, T. G. Fox, Jr.: J. Am. Chem. Soc., 73, 1904 (1951)

32）中島章夫：第 3 回 ポリビニルアルコール討論 会 (1963)

33) P. J. Flory, C. A. J. Hoeve, A. Ciferri: J. Polymer Sci., 34, 337 (1959)

34) P. J. Flory, A. Ciferri, R. Chiang: J. Am. Chem. Soc., 83, 1023 (1961)

35) A. R. Shultz, P. J. Flory: J. Am. Chem. Soc., 74, 4760 (1952)

\title{
Solution Properties of Vinyl Alcohol-Ethylene Copolymer in Water
}

\author{
by Kyoichiro Shibatani* and Yasuji Oyanagi*
}

Random copolymers of vinyl acetate and ethylene with lower ethylene contents were fractionated into fractions, each having different molecular weight and homogeneous chemical composition. By saponification of these fractions, samples of polyvinyl alcohol partially modified by ethylenic residue (PVAE) were obtained. Aqueous solutions of PVAE exhibit phase separation into two liquid phases in a closed temperature and concentration region. Phase diagrams of PVAE in water were studied as a function of ethylene content and molecular weight of the copolymer. The upper and lower critical solution temperatures become close to each other in a range between 70 and $90^{\circ} \mathrm{C}$ as either ethylene content or the molecular weight decreases, and the polymer whose ethylene content is less than about $3 \mathrm{~mol} \%$ is completely miscible with water at any temperature and concentration. The lower critical solution temperature for the copolymer with infinite molecular weight was ascertained to be the theta temperature by viscosity and sedimentation equilibrium measurements. Solubility of vinyl alcohol polymer in water is considered to be poorest at about $80^{\circ} \mathrm{C}$, and the dilution of the polymer in water seems to be endothermic at higher temperatures and exothermic at lower temperatures.

KEY WORDS Poly(Vinyl Alcohol) / Ethylene-Vinylacetate Copolymer/Water/Solution/Phase
Separation/LCST/ UCST / Viscosity / Sedimentation /

* Central Research Laboratories, Kuraray Co., Ltd. (Sakazu, Kurashiki, Okayama) 